кафедри обліку та оподаткування в галузях економіки, Вінницький національний аграрний університет (21008, м. Вінниця, вул. Сонячна 3, e-mail: gudzenko_nm@i.ua).

PODOLIANCHUK Olena - Candidate of Economic Sciences, Associate Professor, Head of the Department of Accounting and Taxation in the Fields of the Economy, Vinnytsia National Agrarian University (21008, Vinnytsia, 3, Soniachna Str., e-mail: podolianchuk_1@i.ua).

GUDZENKO Nataliya - Candidate of Economic Sciences, Associate Professor, Associate Professor of the Department of Accounting and Taxation in the Fields of the Economy, Vinnytsia National Agrarian University (21008, Vinnytsia, 3, Soniachna Str., e-mail: gudzenko_nm@i.ua).

ПОДОЛЯНЧУК Елена Анатольевна - кандидат экономических наук, доцент, заведующая кафедрой учёта и налогообложения в отраслях экономики, Винницкий национальный аграрный университет (21008, г. Винница, ул. Солнечная, 3, e-mail: podolianchuk_1@i.ua).

ГУДЗЕНКО Наталия Николаевна - кандидат экономических наук, доцент кафедры учёта и налогообложения в отраслях экономики, Винницкий национальный аграрный университет $(21008$, г. Винница, ул. Солнечная, 3, e-mail: gudzenko_nm@i.ua).

УДК 338.488.2:640.43:658.821:339.924 (477)

DOI: 10.37128/2411-4413-2021-2-13

ФОРМУВАННЯ КОНКУРЕНТНИХ ПЕРЕВАГ

РЕСТОРАННОГО БІЗНЕСУ В УКРАЇ̈I B УМOBAX СВРОІНТЕГРАЦІЇ
СТАВСЬКА Ю.В., кандидат економічних наук, доцент, завідувач кафедри менеджменту зовнішньоекономічної діяльності, готельноресторанної справи та туризму, Вінницький національний аграрний університет (м. Вінниця)

ЯХНО Л.С., викладач-методист Відокремленого структурного підрозділу «Немирівський фаховий коледж будівництва, економіки та дизайну Вінницького національного аграрного університету" (м. Немирів)

У статті досліджено прочес інтенсивного розвитку і глобалізації ресторанного бізнесу в Україні як частини сервісного сектору економіки, схильного до впливу багатьох чинників, різних за силою, тривалістю і напрямами впливу в умовах євроінтеграції.

Стаття присвячена розгляду позитивних і негативних факторів впливу на розвиток сфери гостинності. Серед них виділені екстенсивні та інтенсивні. Розглянуто розвиток готельно-ресторанного бізнесу, його вплив на якість життя громадян України. Особливу увагу приділено змінам і підходам, які відбулися в роботі закладів ресторанного господарства (далі ЗРГ) в умовах пандемії та карантинних обмежень. Проведено аналіз розвитку ресторанного 
господарства Украӥни у 2003-2020 рр. Виявлено значне скорочення закладів ресторанного господарства протягом 2014 - 2020 рр.

Обтрунтована безпосередня залежність стану ресторанного господарства Украӥни від розвитку ї̈ економіки. Доведено, щу підприємства індустрії гостинності набувають популярності, інтенсивного розвитку в умовах політичної та економічної стабільності, стійкого економічного становища відвідувачів ресторанних закладів, а також збереженої культурної спадщини. При изьому розвиток ресторанного бізнесу проводиться в умовах євроінтеграції по затверджених програмах. Спостерігається впровадження нових форм $i$ методів обслуговування. Їх аналіз свідчить про взаємозв'язок між розвитком ресторанного бізнесу та інтеграчійних процесів.

У ході дослідження було розроблено алгоритм очінки рівня конкурентоспроможності закладів ресторанного господарства. Встановлено ключові критерії конкурентоспроможності ЗРГ, а саме: рівень задоволеності споживачів, якість наданих послуг, ефективність прочесів управління та організації у ЗРГ, рівень корпоративної та сочіальної відповідальності, конкурентна стратегія ресторану, а також конкурентне середовище закладу.

Ключові слова: ресторанний бізнес, фактори, послуга, сервіс, індустрія гостинності, розвиток, процес.

Рис.: 3. Літ.: 9.

\title{
FORMATION OF COMPETITIVE ADVANTAGES OF RESTAURANT BUSINESS IN UKRAINE UNDER THE CONDITIONS OF EUROPEAN INTEGRATION
}

\author{
STAVSKA Yuliia, \\ Candidate of Economic Sciences, Associate Professor, \\ Head of the Department of International Management, \\ Hotel-Restaurant Business and Tourism, \\ Vinnytsia National Agrarian University \\ (Vinnytsia)
}

\section{YAKHNO Liudmyla, Teacher-Methodologist of Separate structural subdivision «Nemyriv Professional College of Construction, Economics and Design of Vinnytsia National Agrarian University"}

(Nemyriv)

The article examines the process of intensive development and globalisation of the restaurant business in Ukraine as a part of the service sector of the economy exposed to many factors different in strength, duration and areas of influence in the context of European integration.

The article is devoted to the consideration of positive and negative factors influencing the development of hospitality. Among them are extensive and intensive. The development of hotelrestaurant business, its impact on the quality of life of citizens of Ukraine is considered. Particular attention has been paid to the changes and approaches which took place in the work of restaurants in pandemic and quarantine restrictions. The analysis of development of restaurant economy of Ukraine in 2003-2020 was carried out. There was a significant reduction in restaurants during 2014 - 2020.

The direct dependence of the state of the restaurant industry of Ukraine on the development of its economy has been substantiated. It has been proved that the enterprises of the hospitality industry are gaining popularity, intensive development in conditions of political and economic stability, stable economic situation of visitors to restaurants, as well as preserved cultural heritage. Thus development 
of restaurant business is carried out in the conditions of European integration under the approved programmes. There is an introduction of new forms and methods of service. The analysis shows the relationship between the development of the restaurant business and integration processes.

As a result of the study, an algorithm for assessing the level of competitiveness of restaurants was developed. The key criteria for the competitiveness of the restaurants have been established, namely: the level of customer satisfaction, quality of services provided, efficiency of management and organization processes in the restaurants, the level of corporate and social responsibility, competitive strategy of the restaurant and the competitive environment.

Key words: restaurant business, factors, facility, service, hospitality industry, development, process.

Fig.: 3. Ref.: 9.

\title{
ФОРМИРОВАНИЕ КОНКУРЕНТНЫХ ПРЕИМУЩЕСТВ РЕСТОРАННОГО БИЗНЕСА В УКРАИНЕ В УСЛОВИЯХ ЕВРОИНТЕГРАЦИИ
}

\author{
СТАВСКАЯ Ю.В., \\ кандидат экономических наук, доцент, \\ заведующая кафедрой менеджмента внешнеэкономической \\ деятельности, гостинично-ресторанного дела и туризма, \\ Винницкий национальный аграрный университет
} (2. Винница)

ЯХНО Л.С., преподаватель-методист Обособленного структурного подразделения «Немировский профессиональный колледжс строительства, экономики и дизайна Винницкого национального аграрного университета» (2. Немиров)

В статье исследован процесс интенсивного развития и глобализации ресторанного бизнеса в Украине как части сервисного сектора экономики, подверженного влиянию многих факторов, различных по силе, продолжительности и направлениям воздействия в условиях евроинтеграчиии.

Статья посвящена рассмотрению положительных и отрицательных факторов влияния на развитие сфреры гостеприимства. Среди них выделены экстенсивные и интенсивные. Рассмотрено развитие гостинично-ресторанного бизнеса, его влияние на качество жизни граждан Украины. Особое внимание уделено изменениям и подходам, которые произошли в работе учреждений ресторанного хозяйства (далее - УРХ) в условиях пандемии и карантина. Проведен анализ развития ресторанного хозяйства Украины в 2003-2020 г2. Выявлено значительное сокращение заведений ресторанного хозяйства в течении 2014-2020 г2.

Обоснована прямая зависимость состояния ресторанного хозяйства Украины от развития её экономики. Доказано, что предприятия индустрии гостеприимства приобретают популярность, интенсивное развитие в условиях политической и экономической стабильности, устойчивого экономического положения посетителей ресторанных заведений, а также сохраненного культурного наследия. При этом развитие ресторанного бизнеса проводится 8 условиях евроинтеграчии по утвержденным программам. Наблюдается внедрение новых форм и методов обслуживания. Их анализ свидетельствует о взаимосвязи между развитием ресторанного бизнеса и интеграционными процессами. 
Вследствие проведенного исследования был разработан алгоритм оценки уровня конкурентоспособности предприятий ресторанного хозяйства. Установлены ключевые критерии конкурентоспособности УРХ, а именно: уровень удовлетворенности потребителей, качество предоставляемых услуг, эффективность прочессов управления и организачии в УРХ, уровень корпоративной и социальной ответственности, конкурентная стратегия ресторана, а также конкурентная среда заведения.

Ключевые слова: ресторанный бизнес, факторы, услуга, сервис, индустрия гостеприимства, развитие, процесс.

Рис.: 3. Лит.: 9.

Постановка проблеми. Сучасний стан економіки будь-якої країни, яка будує свої відносини в різних сферах за ринковими законами, ставить ресторанний бізнес перед необхідністю формування напрямів розвитку господарської діяльності за специфікою й особливостями ринку, проведення зваженої і обгрунтованої політики з виробництва продукції і надання послуг, необхідних споживачам. Раніше i менеджери, i аналітики стверджували: формування напрямів ефективного розвитку - це процес, який не піддається формалізації. Така точка зору висловлювалася у зв'язку з тим, що на ефективність бізнесу в довгостроковому аспекті впливає велика кількість різноспрямованих факторів, присутніх у всіх без винятку сферах діяльності: від виробництва, реалізації та організації споживання продукції та послуг до планування, прогнозування, контролю, стимулювання. Уявлялося неможливим звести всі ці фактори в єдину систему і спроєктувати на єдину мету. 3 цієї причини при прийнятті рішень управлінцями кожного разу здійснювалося самостійне структурування всього обсягу інформації, а на основі аналізу брався до уваги вплив найбільш значущих чинників. Але навіть при такому структуруванні тільки незначна частка вагомої інформації враховувалася при прийнятті важливих рішень. Це мало об'єктивне пояснення - відсутність чіткої систематизації факторів через їхнє різноманіття, що заважало в повному обсязі враховувати вплив кожного $з$ них.

Підприємства ресторанних послуг є невід'ємною частиною ринкового середовища, значення якого постійно підвищується в залежності від загального соціально-економічного розвитку країни в умовах євроінтеграції. На їх розвиток впливало багато обставин і факторів, у тому числі історичних, побутових умов, рівня якості життя різних верств населення. При цьому саме ці чинники обумовлюють тривалість та інтенсивність впровадження і глобалізації таких послуг.

Аналіз останніх досліджень i публікацій. Базою для наукового дослідження слугували роботи вітчизняних і зарубіжних вчених-економістів, що вивчають проблеми сталого розвитку і функціонування підприємств індустрії гостинності, зокрема В.О. Александрової [1], О.І. Табенської [6], Г.Т. П'ятницької $[4,5]$, В.С. Найдюк [4], Д.А. Панової [3], Дж. Блума [8], М. Мульфорда Хайтоса і Л. Вергана Кастро [9] та ін. Науковці вважають, що фактори зовнішнього і внутрішнього середовища закладу ресторанного господарства впливають на сам процес управління розвитком підприємством, і з цим неможливо не погодитися. В свою чергу, формування конкурентних переваг ресторанного бізнесу - складний, 
безперервний і трудомісткий процес. Складність його полягає у відкритій системі, яка розвивається в динамічному $\mathrm{i}$ часто невизначеному навколишньому середовищі i складається 3 багатьох взаємозалежних елементів, що характеризують можливості будь-якого конкретного підприємства. Тому комплексне вивчення дії факторів як позитивного, так і негативного впливу значно впливає на розвиток сфери гостинності в регіоні і надає можливість формування іï конкурентних переваг.

Формулювання цілей статті. Мета дослідження полягає у систематизації факторів внутрішнього і зовнішнього середовища, які впливають на формування напрямів конкурентних переваг ресторанного бізнесу в умовах євроінтеграції, що обумовлює комплексне дослідження їх дії на розвиток сфери обслуговування.

Виклад основного матеріалу дослідження. Комплексний підхід до проблеми управління розвитком ресторанного бізнесу створює основу для формування конкурентних переваг цієї галузі економіки. Це обумовлює специфіку і підкреслює недоцільність самостійного використання окремих факторів у відриві один від одного і облік їх в якості визначальних у забезпеченні розвитку ресторанного бізнесу. Виникає очевидна необхідність у класифікації факторів для побудови системи причинно-наслідкових зв'язків і відносин на основі вибору ознак угрупування.

У продовження досліджень вітчизняних $\mathrm{i}$ зарубіжних вчених слід відзначити, що системний підхід в управлінні розвитком обумовлює необхідність взаємопов'язаного i взаємозалежного вивчення факторів із урахуванням їх внутрішніх i зовнішніх зв'язків. Систематизація передбачає розміщення досліджуваних явищ або об'єктів у певному порядку 3 виділенням їх взаємозв'язків і співпідпорядкованості [1, с. 90].

На стабільність функціонування i розвиток будь-якого підприємства впливає величезна, практично незлічена кількість факторів різної природи, спрямованості i величини, які мають різноманітні властивості. Однак абсолютизація вимог повного обліку всіх умов може призвести до появи громіздких і технічно нездійсненних досліджень, оскільки вплив факторів на стабільність вихідної інформації проявляється через сотні параметрів і показників. Тому повноту охоплення вихідної інформації слід обмежити вимогою розумної і необхідної достатності. Тут обов'язковою умовою виступає дослідження тих основних факторів, які найбільшою мірою впливають на стабільність функціонування і розвитку окремого підприємства ресторанного бізнесу.

В Україні у 2020 році кількість закладів ресторанного господарства досягла рівня 2003 року. На такий показник вплинула низка факторів, зокрема і пандемія та карантинні умови останніх двох років [7].

Із рис. 1 видно, що економічна криза серйозно торкнулася ресторанного бізнесу - значна кількість закладів у 2020 році після послаблення карантину вже не відчинились. Залишились працювати на ринку найсильніші, найдосвідченіші, фінансово підготовлені заклади ресторанного господарства. Стала жорсткішою конкуренція, що, в свою чергу, обумовило розширення ресторанних послуг, їх якості. Велику вагу почали приділяти спеціальному харчуванню - екологічне, 
вегетаріанське, веганське (сирове), використанню високоякісної сировини для виготовлення та відповідного посуду. Таким чином, в окремих випадках виникає, а в інших - набуває розвитку адаптація послуг під відвідувачів. Стає повсякденним, за їх бажанням, пакувати страви, що залишилися на столі, показувати в меню як формується цінова політика закладу. Це вимагає від рестораторів відповідних знань, умінь, обізнаності у розвитку ресторанного бізнесу i, як результат, застосування нових методів і форм обслуговування.

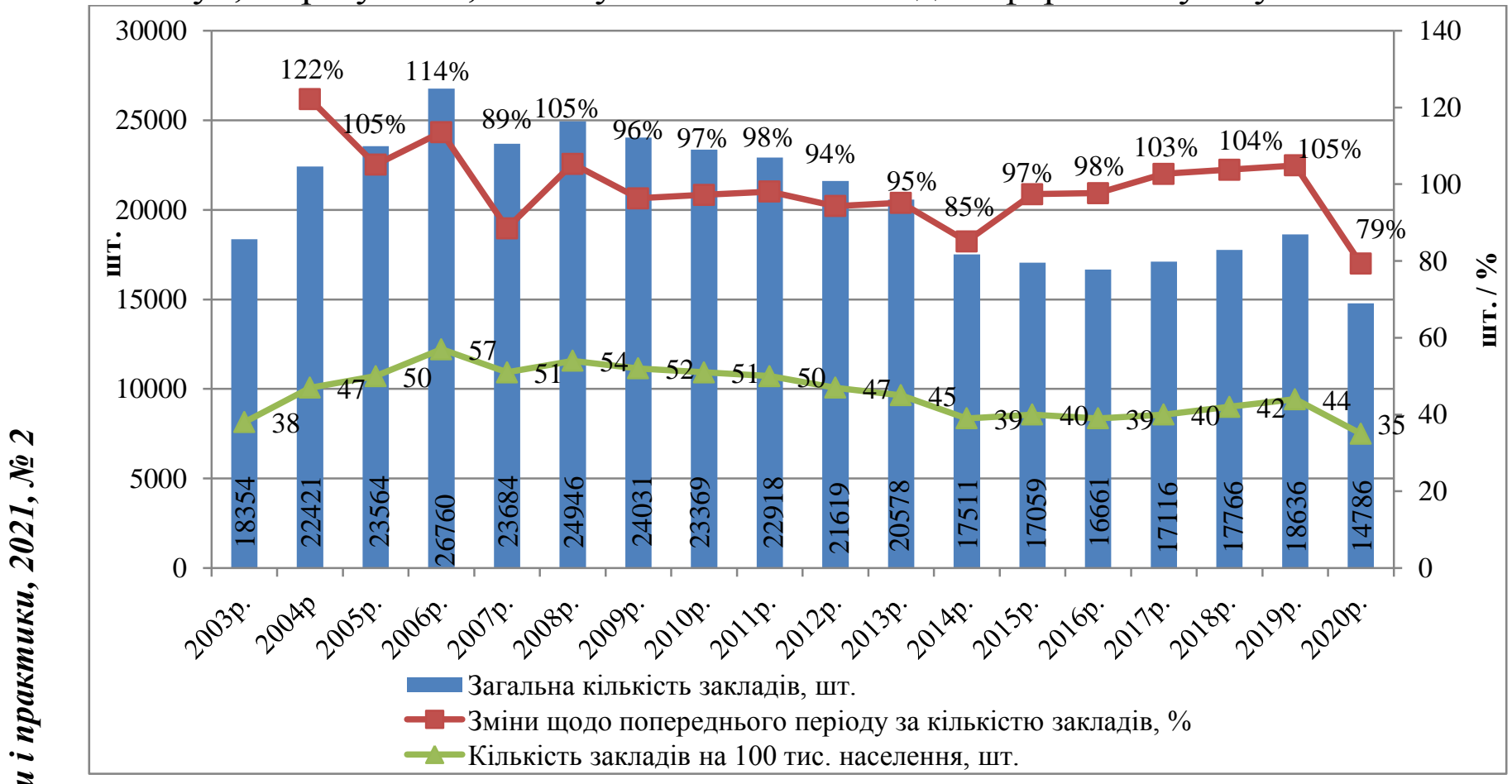

Рис. 1. Розвиток ресторанного господарства в Україні у 2003-2020 pp.

Дюсерело: побудовано авторами на основі [7]

У той же час, грунтуючись на системному підході, слід розглядати вплив прийнятих до вивчення факторів у взаємозв'язку. Наприклад, високий рівень стабільності можливо досягнути шляхом повного і своєчасного забезпечення виробничого процесу необхідними за кількістю і якістю ресурсами, обладнанням, високопрофесійними кадрами, відповідною інформацією і т.п.

Ефективне використання цих ресурсів має визначатися не тільки адаптацією до змін зовнішнього середовища, а й формуванням кращої зміни зовнішніх і внутрішніх факторів. При цьому вплив на окремі фактори внутрішнього середовища внаслідок синергічного ефекту не завжди приводить до отримання відповідного бажаного результату (рис. 2).

Нині ринок ресторанного бізнесу дуже конкурентоспроможний. Щоб виділитися у цьому переповненому ринку, важливо зрозуміти основні конкурентні переваги у сфері ресторанного господарства та знати, де зосередити зусилля. Крім того, індустрія гостинності - підприємства готельного, ресторанного сервісу, відпочинку та дозвілля - завжди була об'єктом пильної уваги органів державного управління. Ця обставина пов'язана 3 двома факторами:

1. Підприємства індустрії гостинності формують і надають послуги з метою задоволення фізичних, духовних та моральних потреб населення i, як правило, 
користуються підвищеним споживчим попитом, незалежно від соціального стану і матеріального достатку громадян.

2. Низка послуг підприємств індустрії гостинності, так само як i технологічний процес їх виробництва, передбачають підвищену соціальну відповідальність перед громадянами. Питання гігієнічної безпеки, дотримання прав та інтересів споживачів не залишаються поза увагою та контролю із боку держави.

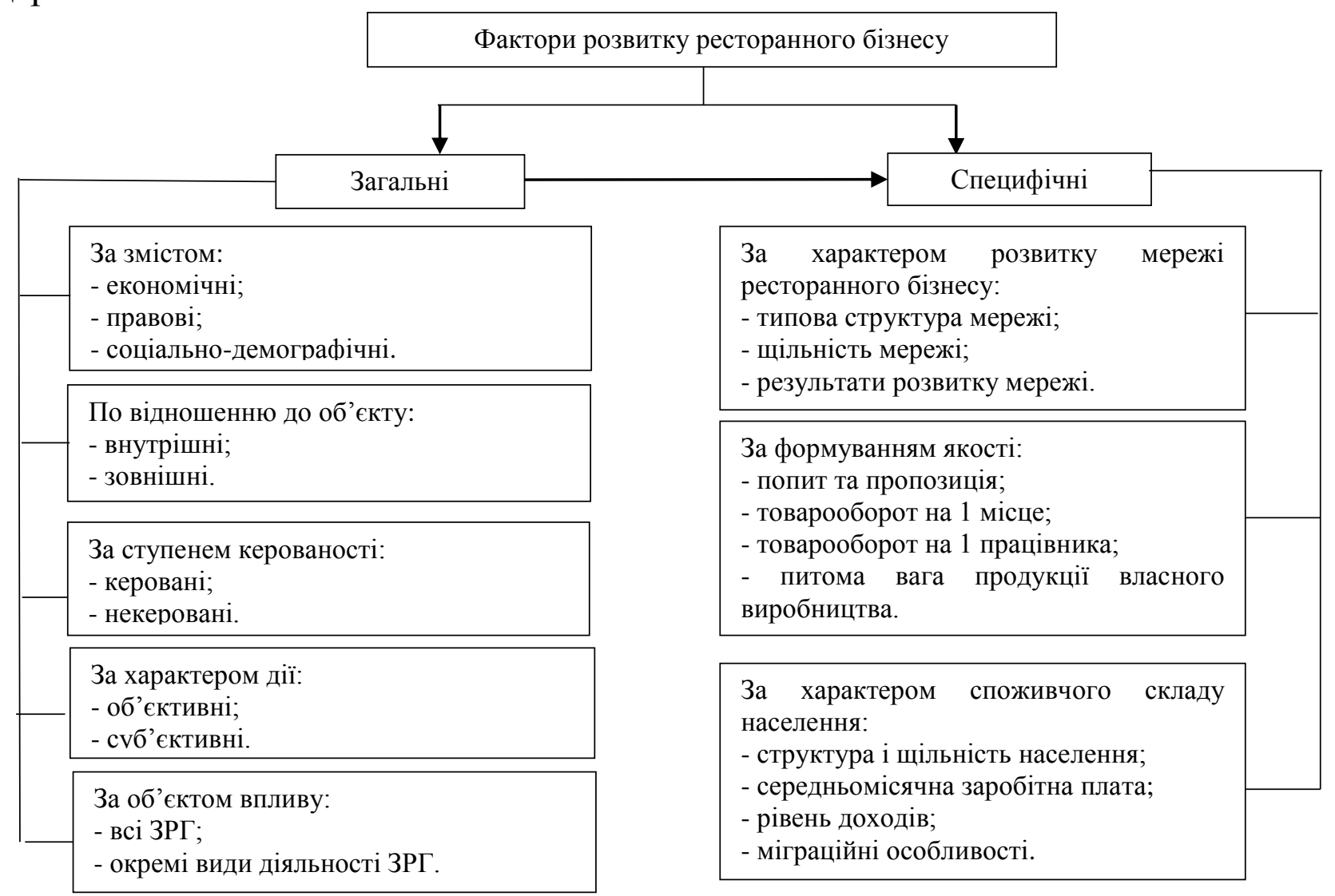

Puc. 2. Систематизація факторів розвитку ресторанного бізнесу

Джерело: побудовано авторами на основі [3, с.114]

Одним із не менш важливих факторів формування конкурентних переваг ресторанного бізнесу є територія, що представляє собою соціально-економічний простір, де розвивається ресторанне господарство.

Вплив економічних і фінансових факторів на формування конкурентних переваг сфери гостинності (таких, як зміна економічної і фінансової ситуації, рівня прибутків населення) обумовлений тим, що між тенденціями розвитку готельно-ресторанного бізнесу i економіки регіону спостерігається тісний взаємозв'язок. Як правило, від економічного розвитку регіону залежить рівень розвитку матеріально-технічної бази та інфраструктури сфери гостинності $[1$, c. 90$]$.

До соціальних чинників, що впливають на формування конкурентних переваг ресторанного бізнесу в умовах євроінтеграції, перш за все, потрібно віднести збільшення вільного часу у населення (скорочення робочого часу, збільшення тривалості щорічних відпусток), що, в поєднанні зі зростанням рівня життя, означає збільшення чисельності нових потенційних клієнтів, підвищення 


\section{ЕФМ \\ http://efm.vsau.org/}

рівня їх освіти, культури, естетичних потреб.

Одним із важливих факторів формування конкурентних переваг, що впливають на розвиток ресторанного бізнесу, є екологічний, який визначає задоволення споживача обслуговуванням, відпочинком через відчуття комфортності, атмосфери гостинності, безпеки і благотворної оздоровчої дії.

Постійний вплив на розвиток сфери гостинності здійснюють демографічні фактори, тобто чисельність населення, статева структура, сімейний стан, кваліфікація персоналу та ін.

$\mathrm{He}$ менше значення мають політико-правові фактори формування конкурентних переваг, а саме: політична ситуація в регіоні, пом'якшення адміністративного контролю у сфері гостинності, уніфікація податкової i грошової політики.

На формування конкурентних переваг ресторанного бізнесу істотний вплив мають і техніко-технологічні чинники, пов'язані з науково-технічним прогресом. Відкриваються можливості для вдосконалення і виробництва нових видів послуг, використання інформаційних технологій.

Отже, до факторів, які впливають на формування конкурентних переваг ресторанного бізнесу відносяться: матеріально-технічні, попит і пропозиція готельно-ресторанних послуг; поглиблення сегментації ринку; вдосконалення засобів і методів масової інформації та зв'язків із громадськістю у просуванні, рекламі і реалізації послуг закладів ресторанного господарства; підвищення професійного рівня персоналу підприємств харчування; пріоритетний розвиток приватного бізнесу в сфері гостинності [4, с. 67].

Вище перераховані фактори поділяються на екстенсивні та інтенсивні. До екстенсивних факторів відносяться: зростання чисельності працівників, збільшення кількості зайнятих працівників у господарському обороті матеріальних ресурсів, будівництво нових закладів ресторанного господарства 3 високим технологічним рівнем.

Інтенсивні фактори - підвищення кваліфікації персоналу, розвиток професійно-кваліфікаційної структури (технічної із вдосконалення матеріальної бази на основі впровадження досягнень i результатів науково-технічного прогресу, включаючи реалізацію програм підвищення культури i якості обслуговування, індустріалізацію, технологізацію і комп'ютеризацію, раціональне використання і розподіл матеріальних ресурсів тощо) [1, с. 90].

Негативні фактори знаходяться у безпосередній залежності від наявності в регіоні розташування ресторану, інфляції, безробіття, занедбаності, екологічних негараздів, відсутності належної уваги до пам'яток культури тощо.

Особливе місце для прибутковості підприємств індустрії гостинності займає сезонність. Під сезонністю розуміють властивість клієнтських потоків концентруватися в певних містах протягом невеликого періоду часу. Так, новорічні, різдвяні та інші свята обумовлюють перевантаженість підприємств готельно-ресторанного бізнесу.

В останні роки помітно зростає кількість факторів, що впливають на попит ресторанних послуг, який різко диференціювався: споживачі з високим рівнем прибутків висувають високі вимоги до якості послуг підприємств індустрії 
гостинності. У зв'язку з цим до чинників, що визначають поведінку споживача, відносять мотиви і причини. В якості основних мотивів у споживачів готельних і ресторанних послуг виступають:

- фізичні (потреба у відпочинку, підтримання здоров'я, розваги, психологічна розрядка);

- культурні - бажання більше дізнатися (фольклор, музика, мистецтво, танці, живопис, релігія, природа);

- міжособистісні бажання «втекти» від рутини, прагнення відвідати друзів, родичів, завести нові знайомства тощо;

- престижні - бажання підвищити свій соціальний статус (турбота про репутацію, потреба у визнанні, а також більшої уваги 3 боку інших людей, прагнення бути оціненим по заслугах) [4, с.68].

Проведене Асоціацією готельних об'єднань та готелів міст України опитування представників ресторанного бізнесу 3 різних регіонів України показало, що 58\% із них намагаються стежити за модними тенденціями ринку, а свій ресторан - зробити ексклюзивним і популярним [7]. Так, вводиться виготовлення окремих страв безпосередньо на столі за участю гостей; подача страв, притаманних регіону; впровадження днів національних кухонь інших країн; введення компліменту ресторану; надається можливість on-line замовлення.

Для будь-якого ресторану кухня може бути основною конкурентною перевагою. Ресторани, які відомі своїми стравами, мають значні переваги при отриманні гарної репутації, шляхом передачі інформації про якість блюд, що готуються, безпосередньо клієнтами. Це означає, що спілкування гостей, які побували в ресторані й залишилися задоволеними, в колі друзів або сім'ї призведе до додаткової реклами підприємства, що, в свою чергу, є вільною формою маркетингу. Для набуття репутації кухні для гурманів необхідно мати талановитого кухара, носія знань унікальних рецептів і страв, а також найсвіжіші інгредієнти. Результатом таких зусиль повинні стати відвідувачі ресторану, що віддають йому перевагу виключно через гарний смак страв. Для додаткового посилення цих якостей можливо запросити ресторанного критика відвідати заклад і заохочувати клієнтів залишати відгуки на сайтах закладу.

Авангардом ексклюзива стала кухня стилю «fusion» (змішана); другий напрям, що сьогодні в попиті у споживача, - низькокалорійне меню (східна кухня, особливо японська і китайська), хоча безпосередньо після фінансової кризи в українських ресторанах переважає українська національна кухня. Формується і спостерігається зростання популярності італійської кухні, а також кухні середземноморської спрямованості.

Ціна є основною конкурентною перевагою для окремих ресторанів. Ідея використання стратегії, заснованої на ціноутворенні, позиціонує ресторан як lowcost у тому цільовому сегменті ринку, де він знаходиться. Ресторани, які зосереджуються на ціні в якості головної конкурентної сили, як правило, мають більш низький прибуток. Разом із тим, вони також можуть генерувати великий обсяг продажів в якості лідера в сегменті low-cost. Прикладом підприємств, які використовують ціну як основну конкурентну перевагу, $є$ ресторани швидкого харчування. 
Отримали розвиток в Україні ресторани з помірною ціновою політикою, розраховані на гостей із середнім рівнем прибутку. Попит на такі ресторанні послуги, на відміну від високоприбуткової групи, більш еластичний, і тому знаходить відображення у формуванні пропозиції: активно розвиваються ресторани із середнім рівнем цін. Їх концепція може бути найрізноманітнішою та динамічно мінливою, яка забезпечує адаптацію бізнесу до змін сучасності.

Сервіс $\epsilon$ ще однією можливою конкурентною перевагою. Ресторани вищого рівня часто зосереджуються на обслуговуванні як основі конкурентоспроможності. Обслуговування в ресторанному бізнесі у цілому означає мати добре обізнаний, уважний обслуговуючий персонал, своєчасно надавати гостям їжу і напої, швидко реагувати на побажання і скарги клієнтів та надалі проводити роботу над помилками, щоб максимально задовольняти гостей. Складність полягає у гармонійному поєднанні ціни та обслуговування. Так, згадані вище ресторани швидкого харчування не відзначаються зразковим обслуговуванням, оскільки їх робота передбачає працю із якомога більшою чисельністю клієнтів і швидким виконанням замовлень. Таким чином, вже первісно закладена інша модель обслуговування.

Головною конкурентною перевагою ресторану, крім кухні, $є$ атмосфера закладу, яка зацікавлює гостей його відвідувати та розповідати про побачене. Коли ресторан відомий своєю атмосферою, він набуває шанувальників, завсідників, які, в свою чергу, перетворюють заклад у «модне місце». Для розвитку цього фактору конкурентоспроможності ресторану слід докласти певних зусиль - використовувати професійного дизайнера інтер'єру, надати обстановці відповідної концепції, попрацювати над меню і цільовою аудиторією. Другий елемент, що формує атмосферу, - музика в ресторані. Для більшості відвідувачів вона має не менш важливе значення, ніж кольорове оформлення інтер'єру, і робить важливий внесок в успіх бізнесу. Після зазначеного власникам слід створити свій неповторний стиль меню, вивіски і рекламний матеріал [5, с. 125].

Додаткові розваги в ресторані також впливають на його конкурентоспроможність. У зв'язку із значною адаптацією відвідувачів ресторанів до традиційних видів пропонованих розваг на ресторанному ринку виникла нова тенденція - суміщення несумісних раніше форматів, наприклад, клуб і кафе, галерея та ресторан, салон краси і кав'ярня тощо. Слід зауважити, що лідерські позиції утримують інтелектуальні розваги [1, с. 91].

Імідж закладів ресторанного господарства в сучасному бізнесі є основним фактором конкурентоспроможності. Повністю змінити імідж ресторану для його подальшого функціонування - це не рідкість у ресторанному бізнесі. Причини цього різні, а мета - збільшення прибутків. Зміни стаються через бажання нових власників не залишати спогадів про минулий заклад, удосконалення існуючого управління тощо. Проте, можливо стверджувати: якщо справи ресторану йдуть не дуже добре, напевно прийшов час створення нового іміджу. Виникають сумніви щодо існуючого ризику при зміні іміджу закладу. Надамо окремі рекомендації до їх проведення, щоб вони пройшли успішно для підприємства та його власника.

1) Створення плану. Керівник підприємства ресторанного господарства повинен чітко продумати зміну іміджу закладу. Недостатньо мати почуття 
незадоволеності, необхідно усвідомлювати напрям змін або удосконалення ресторану. Для цього необхідно опрацювати всі деталі змін, продумати їх послідовність та строки виконання робіт. У розробку плану входить багато деталей: від кольору фарби до маркетингу. I перевіряти кожну з цих деталей слід на кожному з кроків до здобуття нового іміджу, при цьому не приймаючи постійних рішень «по ходу». Всі дії повинні бути максимально стабілізовані і структуровані до моменту початку перетворення. При запуску будь-якого бізнесу, в період планування і подальшого функціонування перетворень слід провести дослідження ринку. Головним питанням повинна стати відповідність іміджу поставленій меті. Перед тим як перейти на новий рівень створення іміджу, слід переконатися в досконалості огляду ринку ресторанних послуг, проведених формах досліджень зовнішнього середовища, потребах основної групи споживачів, можливому задоволенню гостей ресторану майбутніми змінами. Наприклад, при створенні в маленькому містечку далеко від обласного чи районного центру китайського ресторану з доставкою, можлива ситуація, коли, в кінцевому підсумку, зазнає збитків і китайський ресторан, і доставка, і засновник. Однак, якщо дослідження показують, що саме в цьому регіоні, саме в цьому місті жителі настільки люблять китайську іжу, що тільки і чекають, коли ж з'явиться китайський ресторан, ще й із доставкою, тобто саме це користується великою популярністю i, що також $є$ обов'язковим пунктом, у цьому сегменті мало конкуренції, то, цілком можливо, що ця ідея буде успішною та прибутковою. При цьому глибокий аналіз ринку буде затратним, але це буде дешевше, ніж змінити все для того, щоб виявити відсутність ринку для створеногого закладу. Подібне дослідження має важливе значення для будь-якого бізнесу і ресторани особливо його потребують [5, с. 132].

2) Клієнт повинен все знати. У деяких ресторанах зміни відбуваються без врахування інтересів постійних клієнтів. Проте, змінюючи імідж, є вірогідність змусити людей відчувати себе некомфортно і невпевнено за умови, якщо вони не розуміють, що відбувається. Наприклад, відкриваючи ресторан при малих капіталовкладеннях, на виході отримуємо заклад класу економ, куди із задоволенням приходять клієнти, які не мають великих коштів. Із часом, отримавши авторитет та прихильність клієнтів, ресторан потребує і претендує на подальший розвиток. Власник приймає рішення орієнтуватися більше на сімейні пари 3 дітьми, після чого проводить низку перетворень і вводить дитяче меню, ймовірно навіть додатково - розваги для дітей. Далі знову проводить аналіз, приймає рішення поміняти імідж (до цього часу засобів на радикальні зміни у нього достатньо) і він різко змінює бюджетний заклад на ресторан класу преміум із аніматорами, дитячою кімнатою та іншими масштабними розвагами для дітей. Здавалося б, концепція та ж - сімейне кафе. Водночас, великі витрати і розширення пропонованих послуг принесе збільшення вартості цих самих послуг. У ситуації відвідування ресторану сімейною парою у черговий раз із метою поїсти морозива, з'ясується, що їх «dress cod» та матеріальне становище не відповідають новому іміджу закладу. Тоді і настає почуття дискомфорту та невпевненості у клієнтів. Це призведе до втрати постійних споживачів. Із цього робимо наступні висновки: 
1. Клієнти зобов'язані знати про всі зміни, що відбуваються.

2. Зміни повинні відбуватися поступово, щоб клієнти могли до них звикнути.

А ось досягти виконання цих пунктів можливо, зробивши це частиною маркетингу. Рекламуючи, що ресторан буде новим і поліпшеним, необхідно дати людям зрозуміти, у чому він буде кращим і що вони можуть очікувати. Це особливо ефективно, якщо ресторан зазнає радикальних змін, таких, як зміни в меню, наприклад, а не тільки зміни зовнішнього іміджу самого ресторану. Все це призводить до великого обсягу роботи. Зробити грошові витрати на зміни іміджу ресторану слід до початку цієї роботи, при цьому не забуваючи такі деталі, як зміна рекламної кампанії, знаків, листівок, а також того, що використовується в рекламних цілях. Із огляду на перераховані вище аспекти, відзначаємо наступне: ресторан - це підприємство що потребує, як і будь-яке інше, ефективного керівництва. Для цього слід враховувати такі фактори:

- акцентувати увагу на своїх сильних сторонах і зробити їх значущими для клієнтів;

- проаналізувати конкурентів, визначити їх недоліки та використовувати це їм в противагу;

- визначити власні недоліки і швидко їх усунути;

- постійно створювати нове, що буде головною відмінністю між власним рестораном і рестораном конкурентів;

- цікавитися своєю аудиторією, усвідомлювати, наскільки важливі для них ті чи інші зміни, а потім визначити, як їх досягти.

Отже, створювати концепції, проєктувати меню, правильно підібрати персонал і управляти рестораном - це не тільки складно, але й вимагає багато часу. Саме тому так необхідно грамотно просувати ресторан, тримати в полі зору конкурентів і постійно спілкуватися 3 клієнтами. При цьому, ці завдання слід виконувати, не забуваючи готувати смачні страви і надавати обслуговування екстра-класу. Проте, для підтримки конкурентоспроможності ресторану, його іміджу і марки, існує безліч не настільки масштабних, як перетворення в цілому, але не менш важливих підходів:

1. Використання соціальних медіа для просування. Все частіше соціальні майданчики (наприклад Facebook, Instagram, Twitter) $\epsilon$ способом людського спілкування один із одним, із відомими людьми, політиками, брендами та ін. Просуваючи ресторан, слід розуміти, що користувачі соціальних медіа розраховують на такі чотири ключові моменти:

- акції або знижки. Ексклюзивний купон на знижку, викладений користувачам через Facebook або будь-який інший обраний сервіс, стає потужним рекламним засобом;

- ексклюзивність, недоступну в інших місцях. Регулярна діяльність активно підтримується передплатниками. Публікація фото 3 вечірок, 3 дня відкриття тільки підігріє зацікавленість публіки до закладу. А викладене відео сомельє ресторану, в якому він виділяе винну карту, проводячи таким чином свого роду безкоштовний семінар по виноробству, тільки підкреслить стиль ресторану i, безсумнівно, приверне потрібну аудиторію; 
- інформація про нові продукти. Необхідно, щоб передплатники були в курсі нового меню, а також меню, що діє за системою «Нарру Hours»;

- можливість поділитися думкою. Ресторани повинні дякувати клієнтам за компліменти і реагувати на критику, демонструвати прямий контакт із клієнтами.

2. Меню. Меню є одним із основних елементів ресторану. Меню передає загальну концепцію ресторану для його клієнтів, тому необхідно:

- розробити багато привабливих назв у меню ще в період підготовки. Такі слова, як: «тушкований», «обпалені», «смажений», «випечений», «запечений», «приготований на вугіллі» підкреслюють рівень престижу i, відповідно, збільшують ймовірність сприйняття вартості страви;

- зазначити у назві страви причину, чому це блюдо вважається особливим, відмінним або унікальним. Чи страви 3 яєць по-ранковому свіжі і безпосередньо 3 ферми? Печеться домашній хліб щоранку? Чи виготовлені страви 3 продукції вирощеної чи органічної?;

- «великі інгредієнти для великих описів». Слід вказати будь-які відомі важко помітні елементи, які є в страві. Наприклад, чи містить страва сезонні інгредієнти, які необхідно виділити;

- звідки поступають продукти. Наприклад, мармурова яловичина з Канзассіті, свіжий лобстер із прохолодних вод Південної Африки, свіжа ікра лосося 3 Камчатського краю мають значення для людей;

- необхідно проявляти ретельність. Якщо ресторан пропонує пасту, потрібно пояснити гостям, чи є це «пінгвіні», «капелліні» або «фетучіні». Розказати гостям, що соус, який пропонується сьогодні, безсумнівно відмінний, однак це не просто соус - це «демглас», «вершковий», «тар-тар» тощо. Надаючи більш детальну інформацію, тим самим підвищується сприйняття клієнтами того чи іншого блюда.

Незважаючи на відмінну внутрішню структуру ресторану, слід згадати i індивідуальні риси характеру керівника, який має впоратися 3 таким потужним закладом, must-have ресторатора, адже успішний ресторан починається 3 правильного до нього ставлення i виявлення таких особистих рис як толерантність, почуття бізнесу, позитивна енергія, лідерські навички, товариськість, сучасність, пристрасть до справи, якою займаєшся, наполегливість, можливість збалансувати своє життя як всередині, так і ззовні ресторану. Саме за умови виявлення всіх зазначених якостей, а також згаданих пунктів, що сприяють розвитку як ресторану, так і його конкурентоспроможності, можна стверджувати, що підприємство приноситиме прибуток. І таким підприємством може стати будьякий заклад ресторанного господарства. Для цього варто дотримуватися певних методів при формуванні конкурентних переваг ресторанного бізнесу.

$\mathrm{y}$ межах даного дослідження пропонуємо алгоритм оцінки рівня конкурентоспроможності підприємств ресторанного господарства (рис. 3).

На основі результатів проведеного дослідження стверджуватимемо, що підприємства кожної сфери діяльності потребують розробки специфічних алгоритмів оцінки рівня їх конкурентоспроможності, що спричинено наявністю галузевих особливостей та відмінністю ключових критеріїв успішності їх функціонування. 


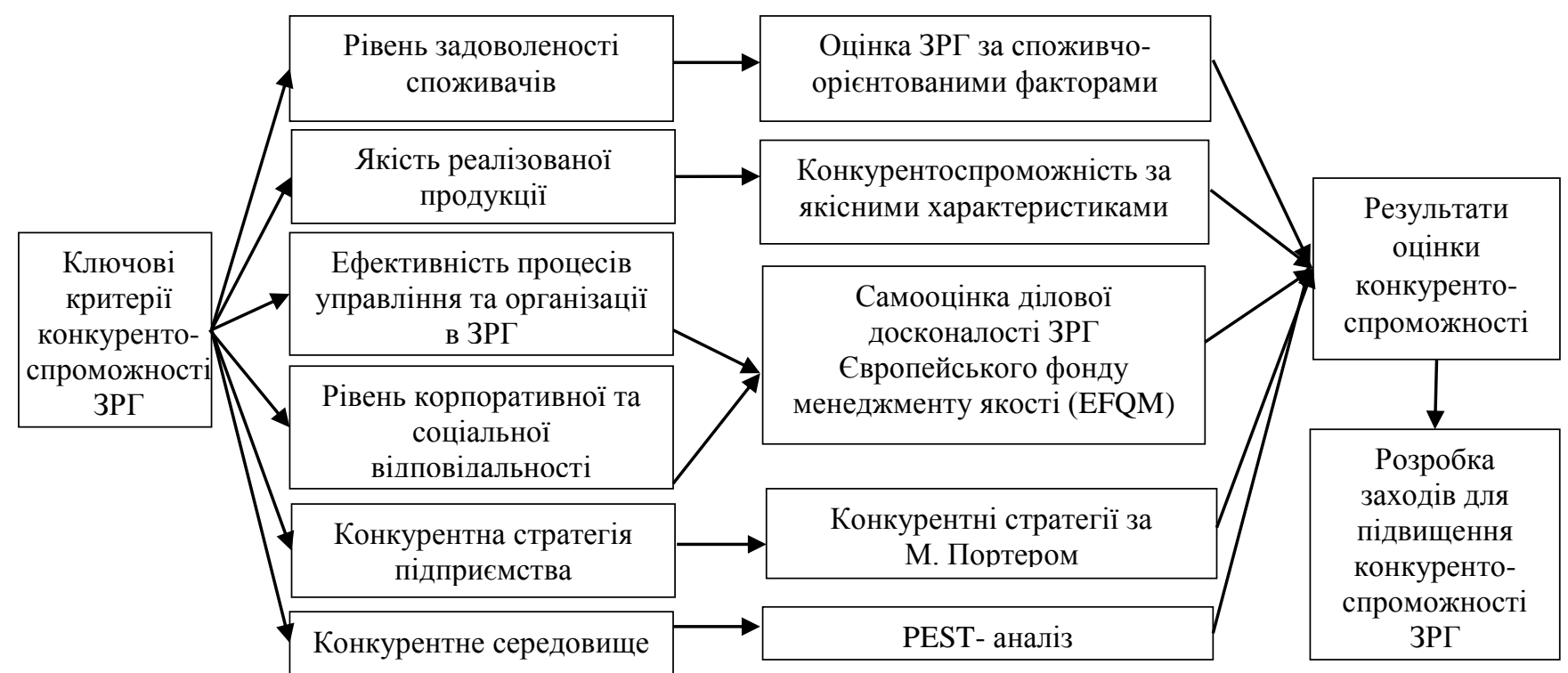

\section{Рис. 3. Алгоритм оцінки рівня конкурентоспроможності закладів ресторанного господарства}

\section{Джерело: вдосконалено авторами на основі [2]}

Висновки. Пандемія «Covid 19» та карантинні обмеження внесли суттєві трансформаційні зміни в характер розвитку ринку ресторанних послуг зменшення прибутків, в основному, в закладах середнього класу, спровокувало різке падіння попиту на послуги підприємств індустрії гостинності та загострило ïх конкуренцію. Ресторани виявились у критичній ситуації, зустрівшись із комплексом нових проблем, які необхідно вирішувати для того, щоб залишитися на ринку. Вирішення цих проблем нерозривно пов'язано зі зміною ринкової стратегії в умовах євроінтеграції. Чітко окреслилися потреби в недорогих сімейних ресторанах (так званої середньої цінової групи), відступивши від утримання і створення як дешевих їдалень та закусочних, так і дорогих ресторанів і кафе. Це вимагає від рестораторів цілеспрямованої роботи над іміджем закладу, його утриманням із метою максимального задоволення потреб відвідувачів за середньою ціновою політикою. Вони повинні бути переконані в раціональному використанні власних коштів.

У процесі дослідження було запропоновано алгоритм оцінки рівня конкурентоспроможності закладів ресторанного господарства, який передбачає виділення основних критеріїв конкурентоспроможності ЗРГ, зокрема, спроможність задовольнити вибагливого споживача ресторанних послуг шляхом аналізу закладу за споживчо-орієнтованими факторами, здійснення самооцінки ділової досконалості ЗРГ за правилами Свропейського фонду менеджменту якості (EFQM) та, як наслідок, розробка заходів щодо підвищення ефективності діяльності ресторанного закладу.

Таким чином, ресторанний бізнес є невід'ємною частиною сервісного сектору в ринковій економіці, роль, значення, а також обсяг наданих послуг якого безперервно зростає у міру загального соціально-економічного розвитку в умовах євроінтеграції. Аналіз досліджених конкурентних переваг формування ресторанного бізнесу свідчить про існування взаємозв'язку між розвитком 
ресторанного бізнесу та інтеграційними процесами. Заклади індустрії гостинності інтенсивніше розвиваються там, де стабільні економічна і політична ситуація, а також різноманітна соціально-культурна інфраструктура.

\section{Список використаних джерел}

1. Александрова В.О. Визначення чинників та їх вплив на розвиток готельно-ресторанного бізнесу. Вісник Національного технічного університету «ХІІІ». Серія: Економічні науки. 2017. № 45 (1266). С. 89-92.

2. Клюева Ю.С. Проблемы совершенствования сервиса на предприятиях гостинично-ресторанного комплекса. Вопросы управления. 2019. № 3 (58). URL: https://journal-management.com/issue/2019/03/24 (дата звернення: 25.04.2021).

3. Панова Д.А. Влияние ресторанного бизнеса на экономическое развитие страны. Молодой учёный. 2019. № 14 (252). С. 114-115.

4. П’ятницька Г.Т., Найдюк В.С. Сучасні тренди розвитку ресторанного господарства в Україні. Економіка та держава. 2017. № 9. С. 66-73.

5. П'ятницька Г.Т. Ресторанне господарство України: ринкові трансформації, інноваційний розвиток, структурна переорієнтація: монографія. Київ: КНЕУ, 2007. 465 с.

6. Табенська О.I. Інноваційні тенденції розвитку ресторанного бізнесу. Економіка. Фінанси. Право. 2018. № 4/2. С. 24-27.

7. Хроники кризиса бизнеса: кого в Украине больше всего накроет штормом коронавируса.

URL:

https://www.epravda.com.ua/rus/ publications/2020/03/19/658296 (дата звернення: 27.04.2021).

8. Bloom J. How are food supply networks coping with coronavirus? BBC News. URL: https://www.bbc.com/news/business-52020648 (дата звернення: 25.04.2021).

9. Mulford Hoyos M., Vergara Castro L., Plata de Plata D. Tienda virtual: social market Colombia. Multiciencias. 2014. P. 268-275.

\section{References}

1. Aleksandrovova, V.O. (2017). Vyznachennia chynnykiv ta yikh vplyv na rozvytok hotelno-restorannoho biznesu [Identification of factors and their impact on the development of hotel and restaurant business]. Visnyk Natsionalnoho tekhnichnoho universytetu «KPI». Serija: Ekonomichni nauky - Bulletin of the National Technical University «Kharkiv Polytechnic Institute». Series: Economic Sciences, 45 (1266), 8992 [in Ukranian].

2. Kliueva, Yu.S. (2019). Problemu sovershenstvovanyia servysa na predpryiatyiakh hostynychno-restorannoho kompleksa [Problems of improving service at the enterprises of the hotel and restaurant complex]. Voprosu upravlenyia Management issues, 3 (58). Retrieved from: https://journalmanagement.com/issue/2019/03/24 [in Russian].

3. Panova, D.A. (2019). Vlyianye restorannoho byznesa na ekonomycheskoe razvytye stranu [The influence of the restaurant business on the economic development of the country]. Molodoi uchenii-Young scientist, 14 (252), 114-116 [in Russian].

4. Pjatnycjka, Gh.T. \& Najdjuk V.S. (2017). Suchasni trendy rozvytku restorannogho ghospodarstva $\mathrm{v}$ Ukrajini [The modern trends in the development of the 


\section{ЕФМ \\ http://efm.vsau.org/}

restaurant industry in Ukraine]. Ekonomika ta derzhava - Economy and state, 9, 66-73 [in Ukranian].

5. Pjatnycjka, Gh.T. (2007). Restoranne hospodarstvo Ukrainy: rynkovi transformatsii, innovatsiinyi rozvytok, strukturna pereoriientatsiia [Restaurant industry of Ukraine: market transformations, innovative development, structural reorientation]. Kyiv:KNEU [in Ukranian].

6. Tabenska O.I. (2018). Innovatsiini tendentsii rozvytku restorannoho biznesu [Innovative trends in the restaurant business]. Ekonomika. Finansy. Pravo-Economics. Finance. Law, 4/2, 24-27 [in Ukranian].

7. Hroniki krizisa biznesa: kogo v Ukraine bol'she vsego nakroet shtormom koronavirusa [Chronicles of the business crisis: who in Ukraine will be most covered by a coronavirus storm]. epravda.com.ua. Retrieved from: https://www.epravda.com.ua/rus/publications/2020/03/ 19/658296 [in Russian].

8. Bloom J. How are food supply networks coping with coronavirus? BBC News. bbc.com. Retrieved from: https://www.bbc.com/news/business-52020648 [in English].

9. Mulford Hoyos, M., Vergara Castro, L. \& Plata, de Plata D. (2014). Tienda

\section{Відомості про авторів}

СТАВСЬКА Юлія Вацлавівна - кандидат економічних наук, доцент, завідувач кафедри менеджменту зовнішньоекономічної діяльності, готельноресторанної справи та туризму, Вінницький національний аграрний університет (21008, м. Вінниця, вул. Сонячна, 3, e-mail: usv.urf@ukr.net).

ЯХНО Людмила Сергіївна - викладач-методист, Відокремлений структурний підрозділ «Немирівський фаховий коледж будівництва, економіки та дизайну Вінницького національного аграрного університету» (22800, Вінницька обл., м. Немирів, вул. Гімназійна, 29, e-mail: nfcbed.vnau@gmail.com).

STAVSKA Uliya - Candidate of Economic Sciences, Associate Professor, Head of the Department of International Management, Hotel and Restaurant Business and Tourism, Vinnytsia National Agrarian University (21008, Vinnytsia, 3, Soniachna Str., e-mail: usv.urf@ukr.net).

YAHNO Ludmila - Teacher-Methodologist, Separate structural subdivision «Nemyriv Professional College of Construction, Economics and Design of Vinnytsia National Agrarian University» (22800, Vinnytsia region, Nemyriv, 29, Gymnasium Str., e-mail: nfcbed.vnau@gmail.com).

СТАВСКАЯ Юлия Вацлавовна - кандидат экономических наук, доцент, заведующая кафедрой менеджмента внешнеэкономической деятельности, гостинично-ресторанного дела и туризма, Винницкий национальный аграрный университет (21008, г. Винница, ул. Солнечная, 3, e-mail: usv.urf@ukr.net).

ЯХНО Людмила Сергеевна - преподаватель-методист, Обособленное структурное подразделение «Немировский профессиональный колледж строительства, экономики и дизайна Винницкого национального аграрного университета» (22800, Винницкая обл., г. Немиров, ул. Гимназическая, 29, e-mail: nfcbed.vnau@gmail.com). 